\title{
Application of Metal-Based Nanocatalysts for Addressing Environmental Issues and Energy Demand
}

\author{
Mohamad Hassan Amin (D)
}

check for

Citation: Amin, M.H. Application of Metal-Based Nanocatalysts for Addressing Environmental Issues and Energy Demand. Catalysts 2021, 11, 1521. https://doi.org/10.3390/ catal11121521

Received: 6 December 2021

Accepted: 13 December 2021

Published: 15 December 202

Publisher's Note: MDPI stays neutral with regard to jurisdictional claims in published maps and institutional affiliations.

Copyright: (C) 2021 by the author. Licensee MDPI, Basel, Switzerland. This article is an open access article distributed under the terms and conditions of the Creative Commons Attribution (CC BY) license (https:/ / creativecommons.org/licenses/by/ $4.0 /)$.
School of Science, RMIT University, Melbourne, VIC 3000, Australia; doctoramin@gmail.com

As part of the Glasgow Climate Pact, at COP27 in 2021, world leaders of 197 countries agreed to cut carbon dioxide emissions to prevent a "climate catastrophe". The goal is to limit global temperature rise to 1.5 degrees relative to pre-industrial times. To reach this goal, the use of fossil fuels as the dominant global energy must decline globally by 3 per cent each year until 2050 [1]. However, decarbonising the energy supply may increase energy demand [2]. Therefore, additional effort is required to limit global $\mathrm{CO}_{2}$ emissions to net-zero, and some alternative reliable and cheap energy must be found.

Recently, the application of metal-based nanocatalysts has gained attraction for addressing environmental issues and energy demand. As an example of alternative energy, Fischer-Tropsch synthesis is a promising route for clean and reliable fuel production [3]. This technology involves syngas production (mixture of hydrogen and carbon monoxide) from methane mainly through metal-supported nanocatalysts, converting the syngas to C1-C100 hydrocarbons using heterogeneous metal-based nanocatalysts and refining [3]. The production of syngas from methane is currently carried out using three processes: steam reforming, partial oxidation, autothermal reforming, and a combination of these processes. Some other methods, such as dry and tri-reforming of methane, are still under research [4]. Additionally, some other methods are suggested to reduce emissions and utilise $\mathrm{CO}_{2}$, such as $\mathrm{H}_{2}$ generation by ethanol steam reforming, $\mathrm{CO}_{2}$ methanation, or $\mathrm{CO}_{2}$ hydrogenation to methanol [5-8].

All of the above processes break strong chemical bonds of the reactant molecules (e.g., C-H or C-C). To overcome the energy barrier of strong bond breakage, metal-based catalysts are needed. Therefore, intensive efforts have been devoted by numerous research groups to the development of catalysts that can achieve high catalytic activity and stability. Most researches have focused on investigating the role of metals, bimetal and synergies, supports, promoters, and preparation methods on activity and stability of catalysts.

The most crucial element of each catalyst is the active component that can adsorb and active $\mathrm{CH}_{4}$. Over the past few decades, researchers have examined and reported various active components for catalysing these reactions. A vast range of supported and unsupported catalysts, such as different types of metals, metal oxides, carbides, sulphides, and carbon, have been investigated [9].

Many researchers have investigated the simultaneous presence of two metals to modify the primary catalyst with a second metal [10]. Chen et al. showed that pre-reaction reduces the partial deactivation behaviour of the Ni catalyst and the sintering of the $\mathrm{Ni}$ nanoparticles [5].

The metal only adsorbs $\mathrm{CH}_{4}$, but the $\mathrm{CO}_{2}$ activation step can take place on the support; therefore, the role of support in catalytic activity is vital [11,12]. Ding et al. reported that well-ordered Ni-MCM-41 catalysts might be a promising candidate with anti-sintering and coking ability in partial oxidation of methane [13]. Additionally, Tang et al. demonstrated that the $\mathrm{Ni}$ catalyst supported on mesoporous $\mathrm{La}_{2} \mathrm{O}_{3}$ exhibits higher activity and selectivity in $\mathrm{CO}_{2}$ methanation than the $\mathrm{Ni}-\mathrm{La}_{2} \mathrm{O}_{3}$ catalyst prepared by a conventional solution combustion method [8]. Amin [14] synthesised a novel tri-modal porous silica (TMS) as a support for a nickel catalyst, which gave excellent activity and stability in comparison to 
the Ni catalysts supported on a classically ordered mesoporous silicates support reported in the literature at a relatively low temperature $\left(700^{\circ} \mathrm{C}\right)$. It was found that the morphology of mesoporous supports plays a substantial role in determining catalytic performance. Some researchers, such as $\mathrm{Li}$ et al., reported that $\mathrm{Ni} / \mathrm{C}$ nanocatalysts possessed high catalytic activity and stability in dry reforming of methane [15].

Recently, approaches to achieving improvements in the activity and stability of catalysts have focused mostly on discovering suitable promoters [16,17]. The types of promoters that have been studied include alkali, alkaline earth, transition, and rare earth metal oxides $[18,19]$. For example, Al-Najar et al. studied the effect of $\mathrm{La}_{2} \mathrm{O}_{3}$ as a promoter on the Pt-Pd-Ni/MgO catalyst in dry reforming of methane, which exhibited the highest activity [20].

This Special Issue's findings will help researchers develop more active catalysts for addressing environmental issues and energy demand. However, more research is still needed to find low-cost, sustainable, and energy-efficient ways to convert existing fossil fuels to carbon-free fuels.

Funding: This research received no external funding.

Conflicts of Interest: The authors declare no conflict of interest.

\section{References}

1. Welsby, D.; Price, J.; Pye, S.; Ekins, P. Unextractable fossil fuels in a $1.5{ }^{\circ} \mathrm{C}$ world. Nature 2021, 597, 230-234. [CrossRef] [PubMed]

2. York, R. Decarbonizing the Energy Supply May Increase Energy Demand. Sociol. Dev. 2016, 2, 265-272. [CrossRef]

3. Teimouri, Z.; Abatzoglou, N.; Dalai, A.K. Kinetics and Selectivity Study of Fischer-Tropsch Synthesis to $\mathrm{C}_{5+} \mathrm{Hydrocarbons}_{\mathrm{A}} \mathrm{A}$ Review. Catalysts 2021, 11, 330. [CrossRef]

4. Amin, M.H. A Mini-Review on $\mathrm{CO}_{2}$ Reforming of Methane. Prog. Petrochem. Sci. 2018, 2, 161-165. Available online: https: // crimsonpublishers.com/pps/pdf/PPS.000532.pdf (accessed on 13 December 2021).

5. Chen, Y.-J.; Huang, S.-H.; Uan, J.-Y.; Lin, H.-T. Synthesis of Catalytic Ni/Cu Nanoparticles from Simulated Wastewater on Li-Al Mixed Metal Oxides for a Two-Stage Catalytic Process in Ethanol Steam Reforming: Catalytic Performance and Coke Properties. Catalysts 2021, 11, 1124. [CrossRef]

6. Wen, J.; Huang, C.; Sun, Y.; Liang, L.; Zhang, Y.; Zhang, Y.; Fu, M.; Wu, J.; Chen, L.; Ye, D. The Study of Reverse Water Gas Shift Reaction Activity over Different Interfaces: The Design of Cu-Plate ZnO Model Catalysts. Catalysts 2020, 10, 533. [CrossRef]

7. Liu, Y.; Cui, N.; Jia, P.; Huang, W. In-Situ FT-IR Spectroscopy Investigation of $\mathrm{CH}_{4}$ and $\mathrm{CO}_{2}$ Reaction. Catalysts 2020, 10, 131. [CrossRef]

8. Tang, G.; Gong, D.; Liu, H.; Wang, L. Highly Loaded Mesoporous Ni- $\mathrm{La}_{2} \mathrm{O}_{3}$ Catalyst Prepared by Colloidal Solution Combustion Method for $\mathrm{CO}_{2}$ Methanation. Catalysts 2019, 9, 442. [CrossRef]

9. Newnham, J.; Mantri, K.; Amin, M.H.; Tardio, J.; Bhargava, S.K. Highly stable and active Ni-mesoporous alumina catalysts for dry reforming of methane. Int. J. Hydrog. Energy 2012, 37, 1454-1464. [CrossRef]

10. Modekwe, H.U.; Mamo, M.A.; Daramola, M.O.; Moothi, K. Catalytic Performance of Calcium Titanate for Catalytic Decomposition of Waste Polypropylene to Carbon Nanotubes in a Single-Stage CVD Reactor. Catalysts 2020, 10, 1030. [CrossRef]

11. Amin, M.H.; Sudarsanam, P.; Field, M.R.; Patel, J.; Bhargava, S.K. Effect of a Swelling Agent on the Performance of Ni/Porous Silica Catalyst for $\mathrm{CH}_{4}-\mathrm{CO}_{2}$ Reforming. Langmuir 2017, 33, 10632-10644. [CrossRef] [PubMed]

12. Amin, M.; Tardio, J.; Bhargava, S. A Comparison Study on Methane Dry Reforming with Carbon Dioxide over Ni Catalysts Supported on Mesoporous SBA-15, MCM-41, KIT-6 and $\gamma$-Al2O3 Carrier. In Proceedings of the Chemeca 2013, South Brisbane, Australia, 29 September-2 October 2013; pp. 543-548. Available online: https://scholar.google.com.au/citations?view_op=view_ citation\&hl=en\&user=D5vJu6YAAAAJ\&cstart=20\&pagesize=80\&citation_for_view=D5vJu6YAAAAJ:2osOgNQ5qMEC (accessed on 13 December 2021).

13. Ding, C.; Wang, J.; Li, Y.; Ma, Q.; Ma, L.; Guo, J.; Ma, Z.; Liu, P.; Zhang, K. The Role of Active Sites Location in Partial Oxidation of Methane to Syngas for MCM-41 Supported Ni Nanoparticles. Catalysts 2019, 9, 606. [CrossRef]

14. Amin, M.H. Relationship Between the Pore Structure of Mesoporous Silica Supports and the Activity of Nickel Nanocatalysts in the $\mathrm{CO}_{2}$ Reforming of Methane. Catalysts 2020, 10, 51. [CrossRef]

15. Li, Y.; Wang, Z.; Zhang, B.; Liu, Z.; Yang, T. Dry Reforming of Methane (DRM) by Highly Active and Stable Ni Nanoparticles on Renewable Porous Carbons. Catalysts 2020, 10, 501. [CrossRef]

16. Amin, M.H.; Mantri, K.; Newnham, J.; Tardio, J.; Bhargava, S.K. Highly stable ytterbium promoted $\mathrm{Ni} / \gamma-\mathrm{Al}_{2} \mathrm{O}_{3}$ catalysts for carbon dioxide reforming of methane. Appl. Catal. B Environ. 2012, 119, 217-226. [CrossRef]

17. Amin, M.H.; Tardio, J.; Bhargava, S.K. An investigation on the role of ytterbium in ytterbium promoted $\gamma$-alumina-supported nickel catalysts for dry reforming of methane. Int. J. Hydrog. Energy 2013, 38, 14223-14231. [CrossRef] 
18. Amin, M.; Tardio, J.; Bhargava, S. An investigation on the role of promoters in promoted $\gamma$-alumina-supported nickel catalysts for dry reforming of methane. In Proceedings of the Chemeca 2013, South Brisbane, Australia, 29 September-2 October 2013; pp. 549-557. Available online: https://scholar.google.com.au/citations?view_op=view_citation\&hl=en\&user=D5vJu6YAAAAJ\& cstart=20\&pagesize=80\&citation_for_view=D5vJu6YAAAAJ:KlAtU1dfN6UC (accessed on 13 December 2021).

19. Amin, M.H.; Putla, S.; Abd Hamid, S.B.; Bhargava, S.K. Understanding the role of lanthanide promoters on the structure-activity of nanosized $\mathrm{Ni} / \gamma-\mathrm{Al}_{2} \mathrm{O}_{3}$ catalysts in carbon dioxide reforming of methane. Appl. Catal. A Gen. 2015, 492, 160-168. [CrossRef]

20. Al-Najar, A.; Al-Doghachi, F.A.; Al-Riyahee, A.A.; Taufiq-Yap, Y.H. Effect of $\mathrm{La}_{2} \mathrm{O}_{3}$ as a Promoter on the Pt, Pd, Ni/MgO Catalyst in Dry Reforming of Methane Reaction. Catalysts 2020, 10, 750. [CrossRef] 